\title{
Effect of BHA on cottonseed oil properties during heating and frying
}

\author{
N.A.A. Elneairy* ; A.S. Soliman** and A. Asmaa Shahlol** \\ *Food Sci.\&Tech. Dept.Faci.of Agric;ALFayoum Univ. Egypt \\ **Food Tech. Dept. Fac. of Eng. And Tech. Sebha Univ. Libya
}

\begin{abstract}
The high temperature used during frying, in the presence of oxygen and water, induce important chemical changes of the oils, namely by oxidation, polymerization and hydrolysis, which generate a large number of compounds have negative effect on human health. This research aims to study effect of BHA and type of fried material on physical and chemical changes of cottonseed oil during frying up to $42 \mathrm{hr}$. Cottonseed oil was a good frying, if it is fresh produced because it has all requirements for frying oil. Refractive index, dark color, flow time, acidity and T.B.A. values of oil increased with increasing static heating and frying time up to $42 \mathrm{hr}$. Peroxide value increased in the first hours then fluctuated up to $42 \mathrm{hr}$ of stating heating and frying. Iodine value decreased with increasing static heating and frying time. BHA had little effect on the stability of cottonseed oil during static heating and frying of potato or fish. BHA increased the induction period from 6 to $18 \mathrm{hr}$ during static heating. Results revealed that the total physical and chemical changes during frying fish are higher than that during frying potato. Static heating and frying decreased the unsaturated fatty acids and increased the saturated fatty acids of cottonseed oil. The change of polyunsaturated fatty acids to saturated fatty acids was lower in frying than in static heating. Decreasing of linoleic acid during frying fish was more than of potato frying. Fried food had effect on rate of change, which happened in oil during frying. T.B.A. value, iodine value, acidity were good indicators for changing, which takes place during frying. Peroxide value is not suitable for assessment of changes during static heating or frying. There is no single method suitable for study physical and chemical changes in oil during frying.
\end{abstract}

Key words: Static heating, Frying, potato, Fish, BHA, Cottonseed oil Properties, Fatty acids.

\section{Introduction}

Fried foods have desired flavor, color and crispy texture, which make deep fat fried very popular to consumers (Boskou et al., 2006). Many different types of edible fat and oils are available for frying purposes; these include the animal fats (i.e. lard and tallow) and vegetable oils such as palm oil, rapeseed oil (Low erucic acid), olive oil, soybean oil, cottonseed oil and corn oil (Rossel, 2001b). The choice of frying oil depends on many factors such as availability, price, flavor and stability. Resistance to oxidation during prolonged exposure to high temperature is one the main properties that industrial frying oil should posses (Kochhor and Gertz, 2004). The high temperatures used during frying, in the presence of oxygen and water induce important chemical changes of the oils, namely by oxidation, polymerization, cyclization and hydrolysis (Paul and Mittal, 1997 and Saguy and Dana, 2003). Frying temperature and time, frying oil, antioxidants and the type of fryer affect the hydrolysis, oxidation and polymerization of the oil during frying. This work aims to study the physical and chemical changes of cottonseed oil during frying and the effect of food and antioxidant on this deterioration.

\section{Materials and methods}

\section{Materials:}

Potato: Potato was peeled and cutted to strips 8 $\times 0.8 \mathrm{~cm}$, then fried in batches every batch contains $240-250 \mathrm{gm}$.

Fish: Fish were prepared, packaged and stored at $-20^{\circ} \mathrm{C}$ until frying.

BHA: BHA imported from Tunis (produced by Sotuchoc Company). A definite weight was dissolved in diethyl ether and mixed with oil then the solvent was removed. The final concentration of BHA in oil was $0.02 \%$.

Static Heating: Three liters of cottonseed oil with or without BHA were heated at $180{ }^{\circ} \mathrm{C}$ in frying kettle for 7 days in rate of heating 6 hour every day. Samples were taken every 3 hours and stored at $20^{\circ} \mathrm{C}$ until analysis.

Frying: Frying kettle was filled with 3 Liter of oil. $240-250 \mathrm{~g}$ of prepared potatoes were fried at 180 ${ }^{\circ} \mathrm{C}$ for $12 \mathrm{~min}$. The frying continued for $42 \mathrm{hr}$ at rate 
of heating $6 \mathrm{hr}$. per day. Samples were taken every 3 hr., then stored at $-20^{\circ} \mathrm{C}$ until analysis. The above steps repeated for oil treated with BHA 0.02\%> Frying fish was done according to the above steps except frying time was $8 \mathrm{~min}$.

\section{Methods:}

Referactive Index, Acid value, Peroxide value and Iodine value were determined according to A.O.A.C. (2000).

Color: Color was determined according to the method described by Farag (1995).

Flow time: Flow time was determined according to the method described by Balogun (1988).

Thiobarbituric acid value (TBA): Thiobarbituric acid value was determined according to the method described by Sidwell et al. (1954).

Fatty acid composition: fatty acid esters were prepared according to the method described by IUPAC (1979), then separated and determined by using GLC (perkin-Elmer, 2B Sigma Type).

\section{Results and discussion}

\section{Fresh cottonseed oil:}

The results in Table 1 and Table 6 revealed that cottonseed oil used in this research is nearly good frying oil. It has peroxide value 4.45 , acidity percent less than $0.4 \%$, iodine value 107.01, lauric acid below $3 \%$ and linolenic acid below 3\%. As result cottonseed oil used in this research has most of all specifications which required for frying oil (Russel, 2001a).

\section{Deterioration in cottonseed oil during static heating:}

Results in Table 1 revealed that refractive index, dark color and flow time (as measured for viscosity) increased with increasing time of static heating. Oxidative and chemical changes in frying oils increase free fatty acids, foaming, color and viscosity (Min and Lee, 1996).

Results revealed also that BHA had no effect on color and viscosity of cottonseed oil during static heating up to $42 \mathrm{hr}$. The results indicated that there is no difference in refractive index between oil treated with BHA and oil without BHA up to $12 \mathrm{hr}$ of static heating. Samples treated with BHA had lower refractive index than sample without BHA from 15 $\mathrm{hr}$ up to $42 \mathrm{hr}$ of static heating. On the other hand, peroxide value increased with increasing heating time and reached to around 5.6 after 6 and 18 hrs for oil without BHA and with BHA respectively. (Mohamed, 1991) reported that peroxide value is useful as an indicator of oxidation at the initial stage only. Peroxide value fluctuated after $6 \mathrm{hrs}$. for cottonseed oil without BHA, and after $18 \mathrm{hrs}$. for cottonseed oil treated with BHA up to $42 \mathrm{hr}$. for both treatments. The resulting hydroperoxides are unstable and decompose to secondary oxidative products (Rossell, 2001b). Analysis of products such as hydroperoxide at one point during the frying process provides little information in the start of process only, since their formation and decomposition fluctuate quickly and are not easily predicate (Abdulkarim et al., 2007).

We can also noticed from results T.B.A. value increased with increasing heating time for both samples treated with BHA or without BHA. Cottonseed oil with BHA had lower T.B.A. value than cottonseed oil without BHA up to $21 \mathrm{hrs}$. Acidity percent increases with increasing heating time. There is no differences could be detected between sample treated with BHA and sample without BHA. Hydrolysis is a major chemical reaction that takes place during deep fat frying (Rossan et al., 1999). Iodine value decreased gradually with increasing heating time for both samples, but there is marked change in iodine value from $33 \mathrm{hr}$ to $36 \mathrm{hr}$ heating time. This decrease in iodine value could be attributed to the destruction in double bonds by oxidation and polymerization (Varela and Ruiza, 1998).

Finally, BHA has a little effect on the stability of cottonseed oil during static heating. BHA increased the induction period from 6 to $18 \mathrm{hr}$. The results are in a good agreement with that reported by Augustin and Berry (1983). The results in Table 2 showed the total changes after $42 \mathrm{hrs}$ of static heating. The total changes for cottonseed oil after 42 hrs of static heating were $0.95,6.01,29.01,0.031$, 0.99 and 266.89 for acidity, T.B.A. value, refractive index, color and flow time, respectively.

Meanwhile, the total changes for cottonseed oil treated with BHA were 0.95, 5.86, 28.88, 0.025, 0.97 and 263.89 for acidity, T.B.A. value, refractive index, color and flow time, respectively. Results in the same Table revealed that cottonseed oil treated with BHA had the lower values than untreated cottonseed oil. We could noticed BHA had slight effect on physical and chemical changes in cottonseed oil during static heating for $42 \mathrm{hrs}$. 


\section{Effect of BHA and potato frying:}

Data in Table (3) indicated that acidity, T.B.A. value, refractive index, color and flow time increased with increasing frying time up to $42 \mathrm{hrs}$ for both samples of cottonseed oil treated with BHA or without BHA. On the other hand iodine value decreased with increasing frying time. Peroxide value fluctuated in both samples between increasing and decreasing during frying period. The results are in good agreement with those reported by Mohamed (1991).

It could be also seen from Table (3) cottonseed oil treated with BHA had lower flow time than untreated cottonseed oil up to $15 \mathrm{hrs}$.

The total amount of T.B.A. value changes after $12,24,36$ and $42 \mathrm{hr}$ were 1.66, 4.01, 5.00 and 6.73 and $1.40,3.75,4.65$ and 6.57 for cottonseed oil without BHA and cottonseed oil treated with BHA, respectively. Finally, we can concluded that BHA had slight effect on physical and chemical changes on cottonseed oil during frying potato up to $42 \mathrm{hrs}$. Results are in a good agreement with that reported by Augustin and Berry (1983). BHA may be volatile during first period of frying as result it had weak effects (Berger, 2005).

\section{Effect of BHA and fish frying:}

Results in Table (4) showed that acidity, T.B.A. value, refractive index, color and flow time increased with increasing frying time up to $42 \mathrm{hrs}$ for both treatments. Iodine value decreased with increasing frying time up to $42 \mathrm{hrs}$ for both treatments. Peroxide value fluctuated in cottonseed oil treated or untreated with BHA up to $42 \mathrm{hrs}$. Cottonseed oil treated with $0.02 \%$ BHA had lower T.B.A. value than untreated oil up to $21 \mathrm{hrs}$ of frying. The amount of T.A.B. value changes after $12,24,36$ and 42 hrs were 1.39 , 4.47, 6.34 and 8.05 and 1.30, 4.48, 7.47 and 8.02 for cottonseed oil without BHA and cottonseed oil treated with $0.02 \%$ BHA, respectively. There are no differences between sample treated with BHA and untreated sample in acidity, peroxide value, refractive index, color and flow time up to $42 \mathrm{hrs}$. These results revealed that BHA had slight effect on changes of cottonseed oil properties during fish frying. This may be due to volatilization of BHA in the first period of frying (Berger, 2005).

\section{Total changes in physical and chemical properties:}

Results in Table (5) revealed that the total changes after 42 hrs of frying fish higher than total changes after $42 \mathrm{hrs}$ of frying potato for cottonseed oil treated or untreated with BHA.

This may be due to transfer of polyunsaturated fatty acids from fish to cottonseed oil, as result the changes in cottonseed oil larger and faster during frying fish than during frying potato up to $42 \mathrm{hrs}$.

Presence $0.02 \%$ BHA decreased the amount of increasing T.B.A. value from 6.73 to 6.57 and from 8.05 to 8.02 for frying potato and fish, respectively.

BHA had slight effect on physical and chemical changes during frying (Augustin and Berry, 1983).

\section{Fatty acid composition:}

The fatty acid composition, effect of static heating, type of fried materials and BHA were investigated. The obtained results are shown in Table (6). Fresh cottonseed oil composed of 4:0 (0.3\%); $12: 0$ (0.16\%); 16:0 (18.71\%); 16:1 (0.04\%); 18:0 (2.54\%); 18:1 (27.08\%); 18:2 (47.81); 18:3 (1.72\%) and 20:0 (0.57\%). The results are in a good agreement with those reported by Mohamed (1991) and Salunkhe et al. (1992).

There is a marked decrease in lenoeic acid and marked increase in stearic and palmitic acid with static heating or frying. Results are in a good agreement with those reported by Che-Man and Tan (1999).

Results revealed that both static heating and frying decreased the unsaturated fatty acids and increased the saturated fatty acids in cottonseed oil. This decrease in unsaturated fatty acids could be attributed to the destruction of double bonds by oxidation and polymerization (Varela and Ruiza, 1998).

Total unsaturated/ total saturated fatty acid ratio decreased with heat treatment of cottonseed oil. The change of unsaturated fatty acids to saturated fatty acids was lower in frying than static heating Table (6). This may be due to moisture in foods creates a steam blanket over the fryer and reduces contact with air (Dana et al., 2003 \& Kochhar and Gertz, 2004). Decreasing of lenoleic acid in fish frying more than in potato frying.

The total unsaturated fatty acids decreased from $76.65 \%$ to 74.28 and $71.39 \%$ during frying potato and fish in cottonseed oil without BHA, respectively. Meanwhile, the total unsaturated fatty acids decreased from $76.65 \%$ to 73.36 and $71.82 \%$ during frying potato and fish with addition $0.02 \%$ BHA to cottonseed oil, respectively.

There is no marked effect for BHA during frying. The results are in a good agreement with those reported by Augustin and Berry (1983). 
Table 1. Effect of BHA and static heating on physical and chemical properties of cottonseed oil.

\begin{tabular}{|c|c|c|c|c|c|c|c|c|c|c|c|c|c|c|}
\hline Treatments & & & & hout BI & & & & & & & $0.02 \%$ & ЗНA & & \\
\hline $\begin{array}{c}\text { Properties } \\
\text { Time hr }\end{array}$ & $\begin{array}{c}\text { Acidity } \\
(\%)\end{array}$ & $\begin{array}{l}\text { Peroxide } \\
\text { value }\end{array}$ & $\begin{array}{l}\text { T.B.A. } \\
\text { value }\end{array}$ & $\begin{array}{l}\text { Iodine } \\
\text { value }\end{array}$ & $\begin{array}{c}\text { Refractive } \\
\text { index }\end{array}$ & Color ${ }^{*}$ & $\begin{array}{l}\text { Flow } \\
\text { time } \\
(\mathrm{Sec})\end{array}$ & $\begin{array}{c}\text { Acidity } \\
(\%)\end{array}$ & $\begin{array}{l}\text { Peroxide } \\
\text { value }\end{array}$ & $\begin{array}{l}\text { T.B.A. } \\
\text { value }\end{array}$ & $\begin{array}{l}\text { Iodine } \\
\text { value }\end{array}$ & $\begin{array}{l}\text { Refractive } \\
\text { index }\end{array}$ & Color ${ }^{*}$ & $\begin{array}{l}\text { Flow } \\
\text { time } \\
(\mathrm{Sec})\end{array}$ \\
\hline 0 & 0.27 & 4.45 & 0.25 & 107.01 & 1.4838 & 0.23 & 79.37 & 0.27 & 4.45 & 0.25 & 107.01 & 1.4838 & 0.23 & 79.37 \\
\hline 3 & 0.29 & 4.07 & 0.76 & 106.02 & 1.4848 & 0.25 & 137.06 & 0.31 & 4.37 & 0.77 & 106.83 & 1.4848 & 0.25 & 135.13 \\
\hline 6 & 0.32 & 5.64 & 1.13 & 106.31 & 1.4858 & 0.26 & 159.19 & 0.32 & 5.18 & 0.94 & 106.47 & 1.4858 & 0.26 & 157.22 \\
\hline 9 & 0.33 & 6.51 & 1.38 & 104.87 & 1.4868 & 0.28 & 177.27 & 0.33 & 5.11 & 1.18 & 104.95 & 1.4868 & 0.28 & 176.15 \\
\hline 12 & 0.34 & 5.14 & 1.6 & 103.21 & 1.4878 & 0.31 & 209.41 & 0.34 & 5.33 & 1.16 & 103.48 & 1.4878 & 0.33 & 191.3 \\
\hline 15 & 0.35 & 4.18 & 1.93 & 101.59 & 1.4928 & 0.35 & 216.03 & 0.35 & 5.48 & 1.62 & 100.19 & 1.4918 & 0.36 & 213.45 \\
\hline 18 & 0.39 & 4.35 & 2.65 & 100.5 & 1.4958 & 0.38 & 222.03 & 0.39 & 5.57 & 2.6 & 99.13 & 1.4938 & 0.39 & 226.22 \\
\hline 21 & 0.38 & 4.84 & 2.78 & 97.53 & 1.4991 & 0.51 & 242.18 & 0.45 & 5.1 & 2.72 & 95.31 & 1.4958 & 0.52 & 246.01 \\
\hline 24 & 0.51 & 5.71 & 3.02 & 95.51 & 1.5038 & 0.55 & 256.36 & 0.5 & 4.55 & 3.04 & 94.78 & 1.4998 & 0.55 & 255.12 \\
\hline 27 & 0.56 & 7.64 & 4.18 & 94.58 & 1.5048 & 0.62 & 266.4 & 0.54 & 5.12 & 3.34 & 93.56 & 1.5038 & 0.63 & 264.34 \\
\hline 30 & 0.66 & 9.19 & 3.65 & 93.76 & 1.5058 & 0.7 & 273.31 & 0.66 & 4.76 & 3.64 & 92.87 & 1.5048 & 0.71 & 277.33 \\
\hline 33 & 0.79 & 7.98 & 4.05 & 92.48 & 1.5068 & 0.76 & 287.22 & 0.63 & 4.38 & 3.94 & 91.89 & 1.5058 & 0.76 & 286.18 \\
\hline 36 & 0.91 & 6.31 & 5.29 & 86.72 & 1.5078 & 0.9 & 317.01 & 0.9 & 5.82 & 4.15 & 87.18 & 1.5078 & 0.91 & 313.44 \\
\hline 39 & 1.13 & 5.81 & 5.84 & 83.43 & 1.5128 & 1.14 & 323 & 1.14 & 5.85 & 5.02 & 85.33 & 1.5078 & 1.12 & 321.2 \\
\hline 42 & 1.22 & 5.24 & 6.26 & 78 & 1.5148 & 1.22 & 346.26 & 1.22 & 6.24 & 6.11 & 78.13 & 1.5098 & 1.2 & 343.26 \\
\hline
\end{tabular}

Table 2. Effect of BHA and heating time on total*** physical and chemical properties of cottonseed oil after $42 \mathrm{hrs}$ of static heating

\begin{tabular}{ccc}
\hline Properties & With out BHA & With 0.02\% BHA \\
\hline Acidity (\%) & 0.95 \\
T.B.A. value & 6.01 \\
Iodine value & 29.01 & 0.95 \\
Refractive index & 0.031 & 28.88 \\
Color* & 0.99 & 0.026 \\
Flow time (Sec)** & **Flow time: By using Ostwald. & ***total = (amount of change after 42hrs - amount of change in zero time).
\end{tabular}


Table 3. Effect of BHA and potato frying on physical and chemical properties of cottonseed oil.

\begin{tabular}{|c|c|c|c|c|c|c|c|c|c|c|c|c|c|c|}
\hline \multirow{2}{*}{$\begin{array}{r}\text { Treatments } \\
\text { Properties } \\
\text { Time hr }\end{array}$} & \multicolumn{7}{|c|}{ Without BHA } & \multicolumn{7}{|c|}{ With $0.02 \%$ BHA } \\
\hline & $\begin{array}{c}\text { Acidity } \\
(\%)\end{array}$ & $\begin{array}{l}\text { Peroxide } \\
\text { value }\end{array}$ & $\begin{array}{l}\text { T.B.A. } \\
\text { value }\end{array}$ & $\begin{array}{c}\text { Iodine } \\
\text { value }\end{array}$ & $\begin{array}{c}\text { Refractive } \\
\text { index }\end{array}$ & Color ${ }^{*}$ & $\begin{array}{l}\text { Flow } \\
\text { time } \\
\text { (Sec) }\end{array}$ & $\begin{array}{c}\text { Acidity } \\
(\%)\end{array}$ & $\begin{array}{c}\text { Peroxide } \\
\text { value }\end{array}$ & $\begin{array}{l}\text { T.B.A. } \\
\text { value }\end{array}$ & $\begin{array}{c}\text { Iodine } \\
\text { value }\end{array}$ & $\begin{array}{c}\text { Refractive } \\
\text { index }\end{array}$ & Color* & $\begin{array}{l}\text { Flow } \\
\text { time } \\
\text { (Sec) }\end{array}$ \\
\hline 0 & 0.27 & 4.45 & 0.25 & 107.01 & 1.4838 & 0.23 & 79.37 & 0.27 & 4.45 & 0.25 & 107.01 & 1.4838 & 0.23 & 79.37 \\
\hline 3 & 0.36 & 5.95 & 0.75 & 102.78 & 1.4852 & 0.29 & 209 & 0.34 & 6.11 & 0.8 & 103.29 & 1.4857 & 0.29 & 207.13 \\
\hline 6 & 0.41 & 7.3 & 1.14 & 101.6 & 1.4862 & 0.36 & 215.22 & 0.39 & 7.08 & 1.1 & 101.97 & 1.4862 & 0.36 & 213.46 \\
\hline 9 & 0.42 & 7.95 & 1.15 & 99.29 & 1.4882 & 0.41 & 227.44 & 0.46 & 7.94 & 1.35 & 98.98 & 1.4882 & 0.41 & 225.33 \\
\hline 12 & 0.48 & 8.28 & 1.91 & 97.42 & 1.4902 & 0.48 & 242.13 & 0.47 & 8.4 & 1.65 & 96.65 & 1.4912 & 0.48 & 241.42 \\
\hline 15 & 0.46 & 8.52 & 2.11 & 95.9 & 1.4932 & 0.55 & 263.22 & 0.47 & 9.22 & 2.12 & 94.74 & 1.4932 & 0.55 & 261.36 \\
\hline 18 & 0.49 & 9.18 & 2.99 & 92.6 & 1.4952 & 0.62 & 272.16 & 0.5 & 9.5 & 2.7 & 92.69 & 1.4952 & 0.62 & 279.44 \\
\hline 21 & 0.54 & 9.45 & 3.28 & 92.6 & 1.4962 & 0.71 & 316.37 & 0.57 & 9.38 & 2.78 & 91.94 & 1.4972 & 0.71 & 315.11 \\
\hline 24 & 0.57 & 7.54 & 4.26 & 89.7 & 1.4972 & 0.77 & 321.12 & 0.72 & 9.85 & 4 & 88.95 & 1.4982 & 0.77 & 333.04 \\
\hline 27 & 0.74 & 9.9 & 4.54 & 87.36 & 1.4982 & 0.82 & 336 & 0.83 & 10.27 & 4.04 & 87.96 & 1.5002 & 0.82 & 341.12 \\
\hline 30 & 0.82 & 11.41 & 5.03 & 84.78 & 1.5002 & 0.9 & 349.11 & 0.94 & 11.18 & 4.37 & 84.91 & 1.5022 & 0.9 & 352.03 \\
\hline 33 & 0.94 & 13.7 & 5.2 & 82.85 & 1.5022 & 1.13 & 372.06 & 0.95 & 13.52 & 5.45 & 83.46 & 1.5032 & 1.12 & 370.12 \\
\hline 36 & 1.17 & 12.81 & 5.25 & 80.74 & 1.5042 & 1.24 & 389.12 & 1.15 & 12.94 & 4.9 & 81.26 & 1.5052 & 1.24 & 387.44 \\
\hline 39 & 1.43 & 11.14 & 6.04 & 78.78 & 1.5062 & 1.32 & 403.26 & 1.42 & 10.85 & 6.1 & 79.82 & 1.5072 & 1.33 & 400.18 \\
\hline 42 & 1.57 & 10.94 & 6.98 & 75.57 & 1.5082 & 1.41 & 426.06 & 1.58 & 8.85 & 6.82 & 75.18 & 1.5082 & 1.4 & 428.05 \\
\hline
\end{tabular}

*Color: As absorbance at $450 \mathrm{~nm}$.

**Flow time: By using Ostwald. 
Table 4. Effect of BHA and fish frying on physical and chemical properties of cottonseed oil.

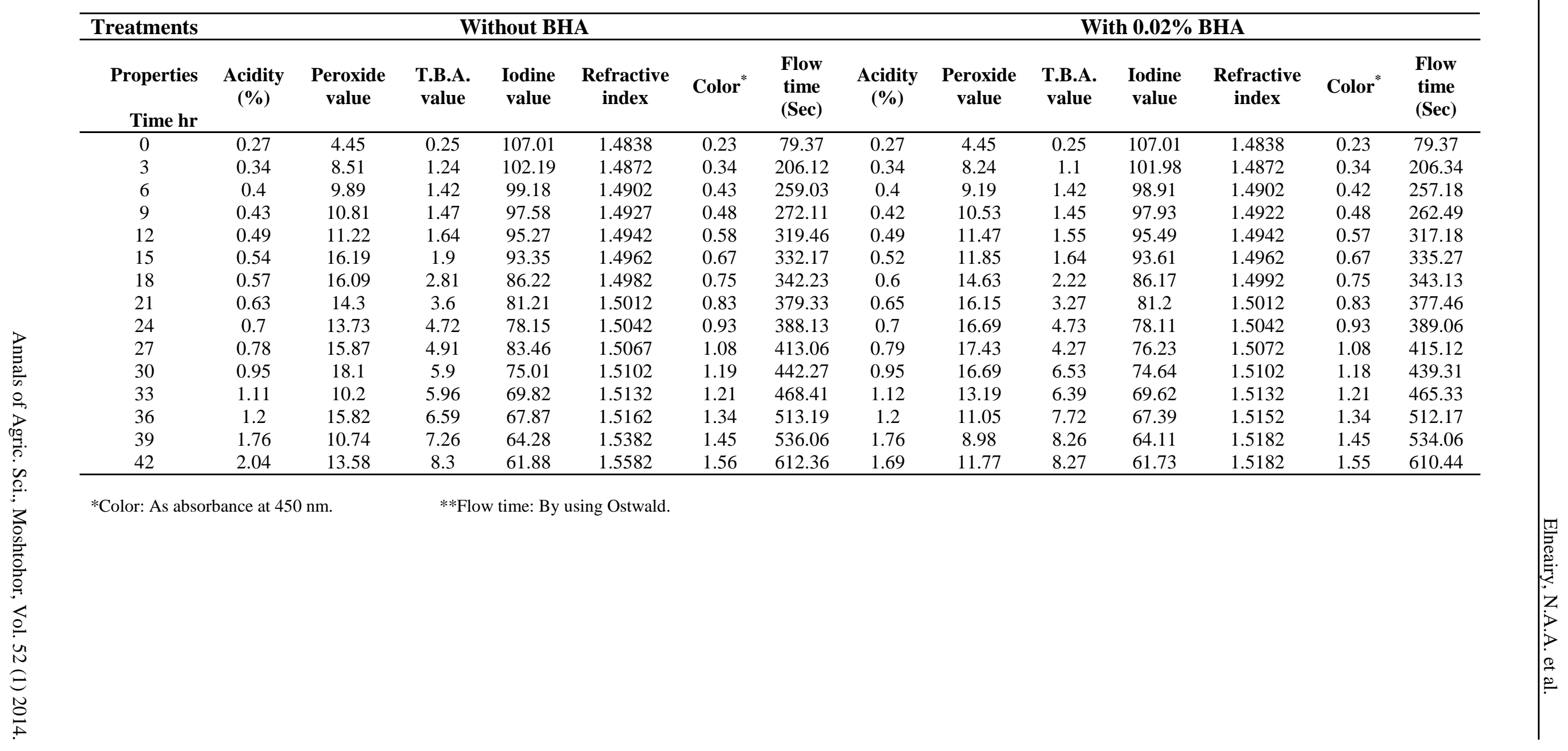


Table 5. Effect of BHA and type of fried materials on total*** changes in physical and chemical Properties of cottonseed oil after 42 hrs of heating.

\begin{tabular}{|c|c|c|c|c|}
\hline Treatments & \multicolumn{2}{|c|}{ 0.0\% ВHA } & \multicolumn{2}{|c|}{ 0.02\% BHA } \\
\hline $\begin{array}{l}\text { Type of materials } \\
\text { Properties }\end{array}$ & Potato & Fish & Potato & Fish \\
\hline Acidity (\%) & 1.30 & 1.77 & 1.31 & 1.42 \\
\hline T.B.A. value & 6.73 & 8.05 & 6.57 & 8.02 \\
\hline Iodine value & 31.44 & 45.13 & 31.83 & 45.28 \\
\hline Refractive index & 0.0244 & 0.0744 & 0.0244 & 0.0344 \\
\hline Color* & 1.18 & 1.33 & 1.17 & 1.32 \\
\hline Flow time $(\mathrm{Sec}) * *$ & 346.96 & 532.99 & 348.68 & 531.07 \\
\hline
\end{tabular}

Table 6. Effect of static heating, type of fried materials and BHA on fatty acids composition of cottonseed oil.

\begin{tabular}{|c|c|c|c|c|c|c|c|}
\hline \multirow{3}{*}{$\begin{array}{c}\text { Fatty } \\
\text { Acids } \\
(\%)\end{array}$} & \multirow{3}{*}{$\begin{array}{c}\text { Fresh } \\
\text { oil }\end{array}$} & \multicolumn{2}{|c|}{42 hr. static heating } & \multicolumn{4}{|c|}{ Frying for $42 \mathrm{hr}$} \\
\hline & & \multirow{2}{*}{$\begin{array}{c}0.00 \% \\
\text { ВНА }\end{array}$} & \multirow{2}{*}{$\begin{array}{c}0.02 \% \\
\text { ВНА }\end{array}$} & \multicolumn{2}{|c|}{ Potato } & \multicolumn{2}{|c|}{ Fish } \\
\hline & & & & $\begin{array}{c}\text { 0.00\% } \\
\text { BHA }\end{array}$ & $\begin{array}{c}\text { 0.02\% } \\
\text { BHA }\end{array}$ & $\begin{array}{c}\text { 0.00\% } \\
\text { BHA }\end{array}$ & $\begin{array}{c}\text { 0.02\% } \\
\text { BHA }\end{array}$ \\
\hline $\mathrm{C}_{4}: 0$ & 0.3 & 0.31 & 0.33 & 0.30 & 0.34 & 1.09 & 1.09 \\
\hline $\mathrm{C}_{12}: 0$ & 0.61 & 1.45 & 0.97 & 0.63 & 0.49 & 1.99 & 1.99 \\
\hline $\mathrm{C}_{14}: 0$ & 0.62 & 2.08 & 1.06 & 0.50 & 0.41 & 1.07 & 0.86 \\
\hline $\mathrm{C}_{16}: 0$ & 18.71 & 22.66 & 23.89 & 19.90 & 21.10 & 19.97 & 20.15 \\
\hline $\mathrm{C}_{16}: 1$ & 0.04 & 1.22 & 0.76 & 0.45 & 0.36 & 1.15 & 1.16 \\
\hline $\mathrm{C}_{18}: 0$ & 2.54 & 4.94 & 6.61 & 4.17 & 4.22 & 3.94 & 3.87 \\
\hline $\mathrm{C}_{18}: 1$ & 27.08 & 26.01 & 25.32 & 27.06 & 28.10 & 27.42 & 27.38 \\
\hline $\mathrm{C}_{18}: 2$ & 47.81 & 39.25 & 39.04 & 45.60 & 43.72 & 42.14 & 42.11 \\
\hline $\mathrm{C}_{18}: 3$ & 1.72 & 1.56 & 1.52 & 1.17 & 1.18 & 0.68 & 1.17 \\
\hline $\mathrm{C}_{20}: 0$ & 0.57 & 0.52 & 0.50 & 0.22 & 0.08 & 0.55 & 0.22 \\
\hline $\begin{array}{l}\text { Saturated fatty } \\
\text { acids }\end{array}$ & 23.35 & 31.96 & 33.36 & 25.72 & 26.64 & 28.61 & 28.18 \\
\hline $\begin{array}{l}\text { Unsaturated fatty } \\
\text { acids }\end{array}$ & 76.65 & 68.04 & 66.64 & 74.28 & 73.36 & 71.39 & 71.82 \\
\hline Us. FA/S. FA ratio & 3.28 & 2.13 & 2.00 & 2.89 & 2.75 & 2.49 & 2.55 \\
\hline
\end{tabular}

\section{References}

A.O.A.C. (2000). Official Methods of Analysis. 17th ED. Of AOAC International Gaithersburg, Maryland USA.

Abdulkarim, S.M.; Long, K.; Lai, O.M.; Muhammed, S.K.S. and Gazali, H.M. (2007). Frying quality and stability of high oleic Moringa oleifera seed oil in comparison with other vegetable oils. Food Chem. 105:1382-1389.

Augustin, M. and Berry, S. (1983). Efficiency of the antioxidants BHA and BHT in palm olein during heating and frying. J. Amer. Oil Chem. Soci., 60(8): 1520-1523.

Balogun, A.M. (1988). Effect of sun drying on proximate composition of lipid characteristics of two fresh water clupeids. Food Chem. $21 ; 1-11$.

Berger, K.G. (2005). The use of palm oil in frying. Frying Oil Series. Malysian Palm Oil Promotion Council, Malaysia, 33-39.

Boskou, D.; Salta, F.N.; Chiou, A.; Troullidou, E. and Andrikopoulos, N.K. (2006). Content of trans trans 2, 4-decadienol in deep fried and pan-fried potatoes. . Eur. J. Lipid Sci. Technol., 108: 109115.

Che Man, Y.B. and Tan, C.P. (1999). Effect of natural and synthetic antioxidants on changes in refined, blenched and deodorized palm olein during deep fat frying of potato chips. AOCS., 76(3): 331-339.

Dana, D.; Blumenthal, M.M. and Saguy, I.S. (2003). The protective role of water injection on oil quality in deep-fat frying conditions. Eur. Food Res. Technol. 217: 104-109.

Farag, R.S.(1995). Physical and chemical properties of fats and oils. Academic Bookshop. Cairo, Egypt.(Arabic)

IUPAC (1979). International Union of Pure and Applied Chemistry. Standard Methods for the Analysis of Oils, Fats and Derivatves. Pergman Press, Oxford. England.

Kochhłar, S.P. and Gertz, C. (2004). Newtheoretical and practical aspects of the frying process. Eur. J. Lipid Sci. Technol., 106: 722-727.

Min, D.B. and Lee, H.O. (1996). Chemistry of lipids oxidation, in food lipid and health, Ed. By 
Donold, R.E. and Min, D.B. New York, NY pp: 241-268.

Mohamed, M.M.M.(1991). Evaluation of certain oils for food utilization. PhD. Thesis, Dept. of Food Science, Faculty of Agriculture, Ain Shams University.

Paul, J.B. and Mittal, G.S. (1997). Regulating the use of degraded oil/fat in deep-fat/oil food frying. Crit. Rev. Food Sci. Nitr. 37: 635-662.

Rossan, G.; Elena, M.C. and Maria, A.B. (1999). Deep fat frying, fundamentals and applications. ISBN Washington. Pp: 1-89.

Rossell, J.B. (2001a). Introduction. In: Rossell, J.B. (Ed). Frying Improving Quality. Woodhead Publishing, Cambridge, England, pp. 1-3.

Rossell, J.B. (2001b). Factors affecting the quality of frying oils and fats. In: Rossell, J.B (Ed)
Improving Quality. Woodhead Publishing, Cambridge, England, pp. 115-164.

Saguy, I.S. and Dana, D. (2003). Integrated approach to deep-fat frying: engineering, nutrition, health and comsumer aspects. J. of Food Engineering, 56: $143-152,162$.

Salunkhe, D.K.; Adsule, R.N. and Kadam, S.S (1992). Corn (Maize), in World oilseed: chemistry, technology and tilization, Van Nostrand Reinhold, New York, Pp: 403:423.

Sidwell,C.G.;Harold,S.;Midada,B.and Mitchell,T.H (1954). The use of Thiobarbituric acid as measure of fat oxidation. J.Am.Oil Chem. Society, 31: 603-606

Varela, G. and Ruiza, B. (1998). Influence of the frying process in real fat intake. J. Lipid Biochemistry, 49: 366-369.

\footnotetext{
تأثير بيوتيليت هيدروكسي أنيسول على خواص زيت بذرة القطن أثناء التسخين والتحمير

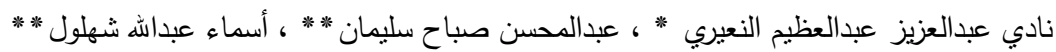

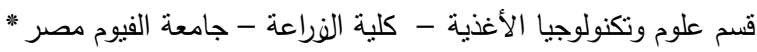

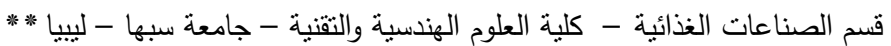

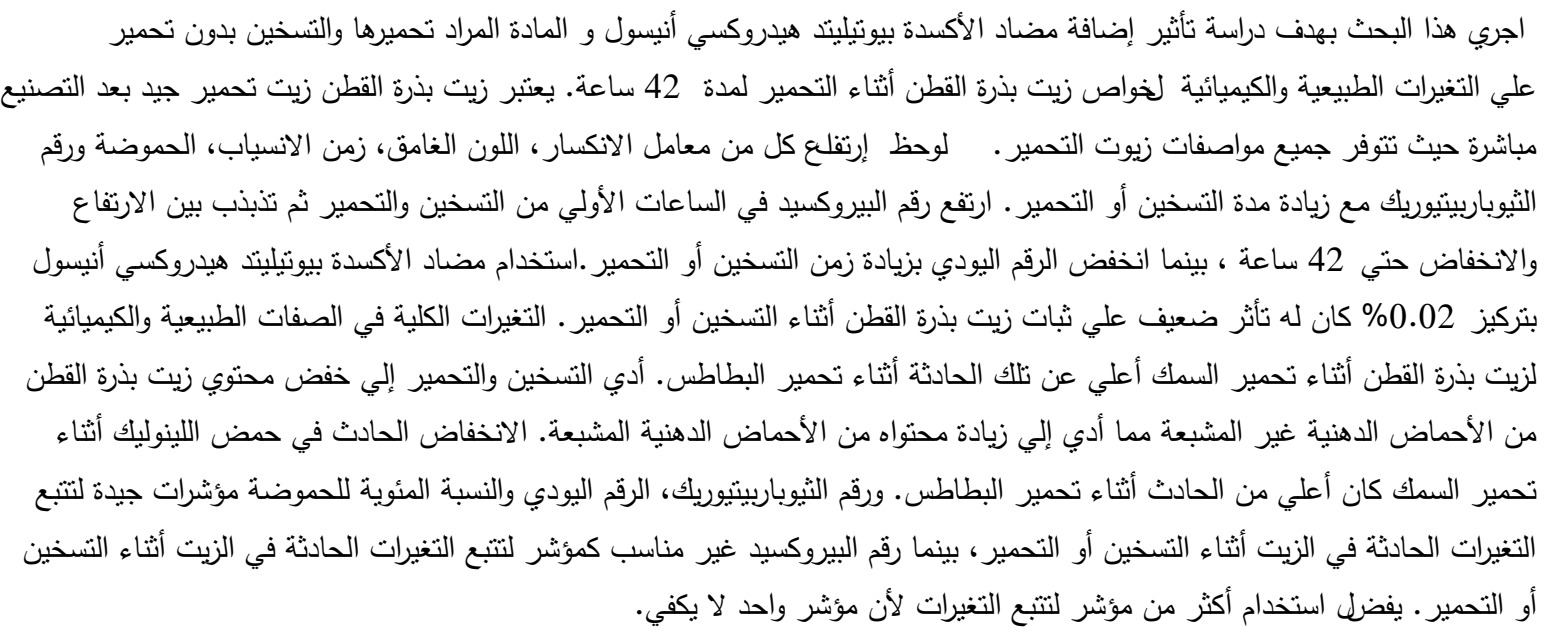

